\title{
Roles of ON Cone Bipolar Cell Subtypes in Temporal Coding in the Mouse Retina
}

\author{
[D Tomomi Ichinose, ${ }^{1,2,3}$ Bozena Fyk-Kolodziej, ${ }^{2}$ and Jesse Cohn ${ }^{1}$ \\ ${ }^{1}$ Department of Ophthalmology and Visual Sciences, Washington University School of Medicine, St. Louis, Missouri 63110, and Departments of ${ }^{2}$ Anatomy \\ and Cell Biology, and ${ }^{3}$ Ophthalmology, Wayne State University School of Medicine, Detroit, Michigan 48201
}

In the visual system, diverse image processing starts with bipolar cells, which are the second-order neurons of the retina. Thirteen subtypes of bipolar cells have been identified, which are thought to encode different features of image signaling and to initiate distinct signal-processing streams. Although morphologically identified, the functional roles of each bipolar cell subtype in visual signal encoding are not fully understood. Here, we investigated how $\mathrm{ON}$ cone bipolar cells of the mouse retina encode diverse temporal image signaling. We recorded bipolar cell voltage changes in response to two different input functions: sinusoidal light and step light stimuli. Temporal tuning in $\mathrm{ON}$ cone bipolar cells was diverse and occurred in a subtype-dependent manner. Subtypes 5 s and 8 exhibited low-pass filtering property in response to a sinusoidal light stimulus, and responded with sustained fashion to step-light stimulation. Conversely, subtypes 5f, 6, 7, and XBC exhibited bandpass filtering property in response to sinusoidal light stimuli, and responded transiently to step-light stimuli. In particular, subtypes 7 and XBC were high-temporal tuning cells. We recorded responses in different ways to further examine the underlying mechanisms of temporal tuning. Current injection evoked low-pass filtering, whereas light responses in voltage-clamp mode produced bandpass filtering in all $\mathrm{ON}$ bipolar cells. These findings suggest that cone photoreceptor inputs shape bandpass filtering in bipolar cells, whereas intrinsic properties of bipolar cells shape low-pass filtering. Together, our results demonstrate that ON bipolar cells encode diverse temporal image signaling in a subtype-dependent manner to initiate temporal visual information-processing pathways.

Key words: light response; parallel processing; patch-clamp; sine wave; subtypes; voltage-gated channels

\section{Introduction}

The retina is the gateway to the visual system. Images are captured by photoreceptors, and then bipolar and ganglion cells encode distinct features of image signaling by forming selective neural streams. Retinal neurons in many species comprise numerous subtypes: $>10$ subtypes of bipolar cells (Boycott and Wässle, 1991; Euler and Wässle, 1995; Wu et al., 2000; Ghosh et al., 2004; MacNeil et al., 2004; Pignatelli and Strettoi, 2004); 15 subtypes of ganglion cells (Sun et al., 2002a,b; Dacey et al., 2003); and numerous subtypes of amacrine cells (Masland, 2001). Multiple subtypes of retinal neurons are thought to encode distinct features of visual signaling, such as motion and color, and these subtypes form multiple neural pathways (Masland, 2001; Wässle, 2004).

Received Sept. 16, 2013; revised May 14, 2014; accepted May 21, 2014.

Author contributions: T.I. and J.C. designed research; T.I., B.F.-K., and J.C. performed research; T.I., B.F.-K., and J.C. analyzed data; T.I. wrote the paper.

This work was supported by National Institutes of Health Grant R01 EY020533, Wayne State University Startup Fund, and grants from Research to Prevent Blindness. We thank Dr. Lukasiewicz and laboratory members for generous support of the experiments; Dr. Kamermans for instructing the sine wave protocols; and Drs. Pan and Walker for constructive comments on the manuscript.

The authors declare no conflicting financial interests.

Correspondence should be addressed to Tomomi Ichinose, Department of Anatomy and Cell Biology, Ophthalmology, Wayne State University School of Medicine, 540 E. Canfield, Detroit, MI 48201. E-mail: tichinos@med.wayne.edu.

J. Cohn's present address: Department of Neuroscience, University of Texas at Austin, 2506 Speedway, NMS 5.234, Austin, TX 78751.

DOI:10.1523/JNEUROSCI.3965-13.2014

Copyright $\odot 2014$ the authors $\quad 0270-6474 / 14 / 348761-11 \$ 15.00 / 0$
Visual signaling pathways have been studied for decades. $\mathrm{X}$ and $\mathrm{Y}$ ganglion cells were characterized as the origins of two separate visual signaling pathways; they respond linearly and nonlinearly to sinusoidal light stimuli and in a sustained and transient fashion to step-pulse light stimuli, respectively (EnrothCugell and Robson, 1966; Cleland et al., 1971). This transient and sustained dichotomy is observed throughout the visual system, from retinal bipolar cells to striate cortical cells (Cleland et al., 1971; Ikeda and Wright, 1974; Awatramani and Slaughter, 2000). Psychophysical experiments further characterized the functions of the two distinct neural pathways: parvocellular (sustained) pathways for encoding color and shape, and magnocellular (transient) pathways for encoding motion (Livingstone and Hubel, $1987,1988)$. These two visual pathways are representative of parallel processing pathways; however, it is not fully understood how this dichotomy corresponds to multiple retinal neuron subtypes.

Technical difficulties have prevented the investigation of bipolar cell physiological functions in the mammalian retina because bipolar cells are small and are not easily accessible (Sterling and Smith, 2004). We have overcome these difficulties by using improved techniques and methods, so as to maintain cells in excellent condition. The retinal preparation was maintained in a cold and oxygenated solution throughout the dissection, and Ames's medium was used during recordings. Also, relatively small-tip pipettes $(\sim 10 \mathrm{M} \Omega)$ were used to stabilize optimal recording conditions. Furthermore, we used neurobiotin injection 
and calretinin [or choline acetyltransferase (ChAT)] immunostaining to verify the subtype of each recorded bipolar cell.

We characterized temporal aspects of visual signaling in six subtypes of $\mathrm{ON}$ cone bipolar cells in the mouse retina using two input functions: step-light and sinusoidal light stimuli. We found that different subtypes of $\mathrm{ON}$ cone bipolar cells tune to distinct temporal visual inputs. Subtypes 7, 5f, and XBC ON bipolar cells were sensitive to changing stimuli, whereas subtypes $5 \mathrm{~s}$ and $8 \mathrm{ON}$ bipolar cells were sensitive to static objects. Subtype 6 was in between these two groups. We also recorded sinusoidal responses with distinct methods to elucidate possible underlying mechanisms for these differences. Collectively, our results indicate that temporal processing begins in $\mathrm{ON}$ bipolar cells in a subtypedependent manner.

\section{Materials and Methods}

Retinal preparation. Animal protocols were approved by the Washington University School of Medicine Animal Studies Committee and the Institutional Animal Care and Use Committee of Wayne State University. The experimental techniques were similar to those described previously (Ichinose and Lukasiewicz, 2012). Mice (28-60 d old; male, C57BL/6J strain; The Jackson Laboratory) were dark adapted overnight, and were killed using carbon dioxide and pneumothorax. An eye was placed in the cooled, oxygenated dissecting solution (see Solution and drugs, below) in a $10 \mathrm{~cm}$ plastic dish. Using a dissecting microscope, the cornea and the lens were quickly removed to make the eye cup, which was incubated with hyaluronidase $(0.5 \mathrm{mg} / \mathrm{ml}$; Sigma) for $15 \mathrm{~min}$ to digest vitreous matter. The vitreous was also gently removed with an extra-fine forceps after enzyme application. Then, the retina was isolated, placed on a piece of filter membrane (HABG01300, Millipore), and cut into slice preparations (250 $\mu \mathrm{m}$ thickness) using a hand-made chopper. Slices used for recording were from the dorsal part of the retina. Retinal dissection and physiological recording procedures were performed in dark-adapted conditions under infrared illumination. The dissection medium was cooled and continuously oxygenated. The retinal preparations were stored in an oxygenated dark box at room temperature until physiological recordings were performed.

Patch-clamp recording. Whole-cell patch recordings and perforated patch-clamp with amphotericin B $(0.3 \mathrm{mg} / \mathrm{ml}$, Sigma $)$ were made from bipolar cell somas in retinal slices by viewing them with an upright microscope (Slicescope Pro 2000) equipped with a CCD camera (Retiga2000R, Q Imaging). Light-evoked EPSPs (L-EPSPs) or light-evoked EPSCs (L-EPSCs) were recorded at the resting membrane potential and at $-60 \mathrm{mV}$, respectively. If the resting potential was above $-40 \mathrm{mV}$, the cell was not used for further analysis. All recordings were made at $30^{\circ} \mathrm{C}$ except for a few bipolar cells used in temperature effect experiments. Liquid junction potentials were corrected after each recording. Electrodes were pulled from borosilicate glass (1B150F-4, World Precision Instruments) with a P1000 Micropipette Puller (Sutter Instruments) and had resistances of 7-11 M $\Omega$. Clampex and Multi Clamp 700B (Molecular Devices) were used to generate waveforms, acquire data, and control LED light stimuli (CoolLED). The data were digitized and stored with a personal computer using Axon Digidata 1440A (Molecular Devices). Responses were filtered at $2 \mathrm{kHz}$ with the four-pole Bessel filter on the Multiclamp 700B (Molecular Devices) and were sampled at $2-5 \mathrm{kHz}$.

Solution and drugs. Retinal dissections were performed in HEPESbuffered extracellular Ringer's solution containing the following (in $\mathrm{mm}): 137 \mathrm{NaCl}, 2.5 \mathrm{KCl}, 2.5 \mathrm{CaCl}_{2}, 1.0 \mathrm{MgCl}_{2}, 10 \mathrm{HEPES}$, and 28 glucose, adjusted to $\mathrm{pH} 7.4$ with $\mathrm{NaOH}$. Physiological recordings were performed in Ames' medium buffered with $\mathrm{NaHCO}_{3}$ (294 mOsm; Sigma). Ames' medium was continuously bubbled with $95 \% \mathrm{O}_{2}$ and $5 \% \mathrm{CO}_{2}$, and the $\mathrm{pH}$ was 7.4 at $30^{\circ} \mathrm{C}$. The intracellular solution contained the following (in mM): $111 \mathrm{~K}$-gluconate, $1.0 \mathrm{CaCl}_{2}, 10 \mathrm{HEPES}, 1.1 \mathrm{EGTA}, 10 \mathrm{NaCl}, 1.0$ $\mathrm{MgCl}_{2}, 5 \mathrm{ATP}-\mathrm{Mg}$, and $1.0 \mathrm{GTP}-\mathrm{Na}$, adjusted to $\mathrm{pH} 7.2$ with $\mathrm{KOH}(269$ mOsm). Sulforhodamine B $(0.005 \%$; Sigma $)$ and neurobiotin $(0.5 \%$; Vector Laboratories) were also added for visualizing bipolar cell axon terminals (Fig. 1; see details below).
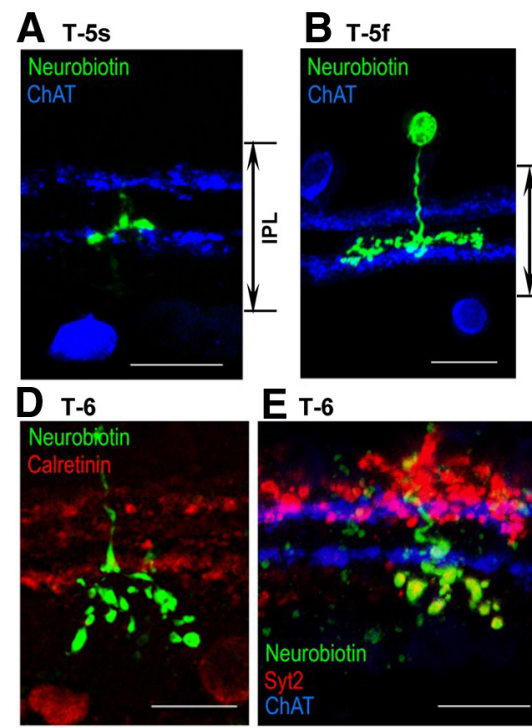

$E_{T-6}$
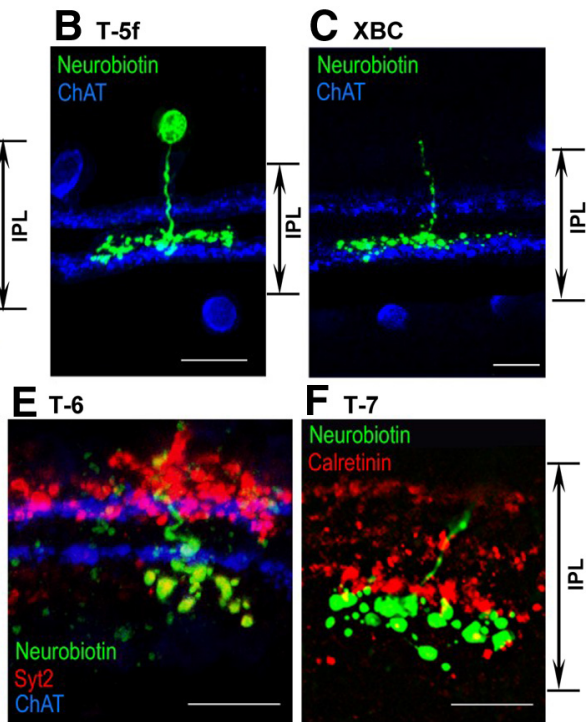

$\mathbf{F}_{\mathrm{T}-\mathrm{7}}$
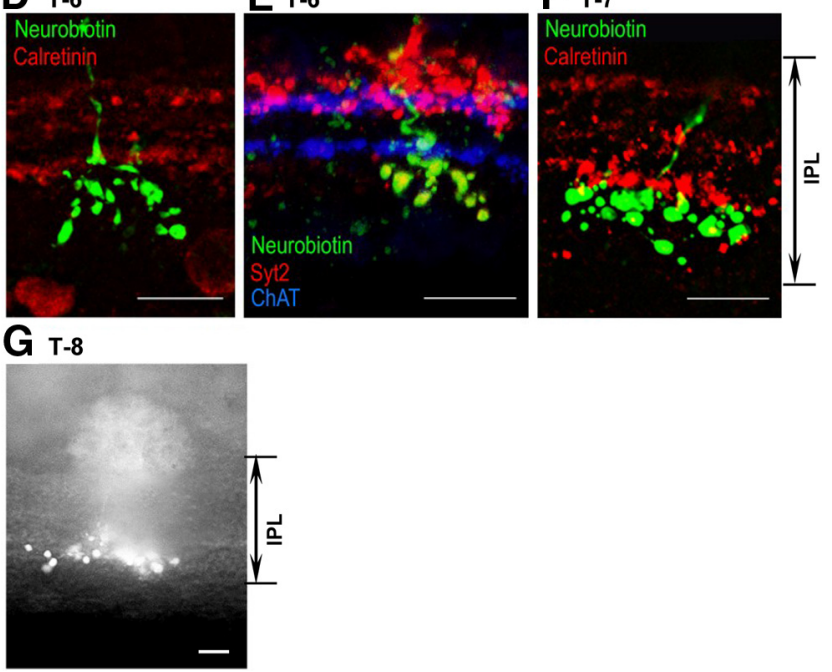

Figure 1. ON cone bipolar cell subtypes were identified by immunohistochemistry after physiological recordings. The IPLs were marked using immunolabeling with calretinin or ChAT antibody. $\boldsymbol{A}$, Subtype 5s ON bipolar cells (neurobiotin, green) identified with ChAT (blue) immunolabeling. $\boldsymbol{B}$, Subtype $5 \mathrm{f} 0 \mathrm{~N}$ bipolar cell. The axon terminal was significantly wider than those of subtype $5 s$ ( $p<0.01, n=7$ for subtype $5 s, n=9$ for subtype $5 f$ ). C, An XBC cell with significantly wider axon terminals was noted next to the inner ChAT band (blue). D, Subtype 6 ON bipolar cell. $\boldsymbol{E}$, Subtype 6 cells (green) were colabeled with Syt2 (red); ChAT bands (blue). $\boldsymbol{F}$, Subtype 7 0N bipolar cell. G, Subtype 8 cell labeled with sulforhodamine B, which was identified immediately after physiological recordings. Scale bars, $10 \mu \mathrm{m}$.

A mixture of inhibitory receptor antagonists including the glycine receptor antagonist strychnine $\left(1 \mu \mathrm{M}\right.$, Sigma), the $\mathrm{GABA}_{\mathrm{A}}$ receptor antagonist (-)-bicuculline methobromide (50 $\mu \mathrm{m}$; Axxora), and the $\mathrm{GABA}_{\mathrm{C}}$ receptor antagonist (1,2,5,6-tetrahydropyridin-4-yl)methylphosphinic acid hydrate (TPMPA, $50 \mu \mathrm{M}$ ) were continuously bath applied during all whole-cell recordings.

Light stimulation. Light stimuli were generated using a CoolLED pE-2 system that was controlled with Clampex software. Either 500 or $360 \mathrm{~nm}$ LED light was projected to the slice preparation through a $60 \times$ objective lens. The diameter of the light was adjusted to $100 \mu \mathrm{m}$, which is slightly larger than the size of the receptive field center of a bipolar cell (Berntson and Taylor, 2000; Borghuis et al., 2013). The spot light illuminated photoreceptors in the vicinity of recording bipolar cells. L-EPSPs and L-EPSCs were evoked in bipolar cells. Initially, step L-EPSPs were recorded in the dark-adapted conditions. If sizable L-EPSPs were observed, the preparations were adapted to continuous background light at the rod photoreceptor saturated level of $4.35 \times 10^{4}$ photons $/ \mu \mathrm{m}^{2} / \mathrm{s}$ for at least 5 min until the amplitude of light-adapted L-EPSPs stabilized. A step light (30\% Weber contrast, $1 \mathrm{~s}$ ) and a sinusoidal light composed of various frequencies $(0.3-20 \mathrm{~Hz}, 30 \%$ Weber contrast) were projected sequentially on top of the background illumination (Fig. 2). L-EPSPs in rod bipolar cells were evoked in response to a step light of $10^{3}$ photons/ $\mu \mathrm{m}^{2} / \mathrm{s}$ for $1 \mathrm{~s}$ in dark-adapted conditions. Sinusoidal patterns were created and customized using MatLab (MathWorks). For some ON bipolar cells, all frequencies of sinusoidal patterns were combined and applied at the same time (Fig. 2E). This pattern was made by adding eight sinusoidal waves of $0.15,0.6,1,2.5,6,9,15$, and $21 \mathrm{~Hz}$. 

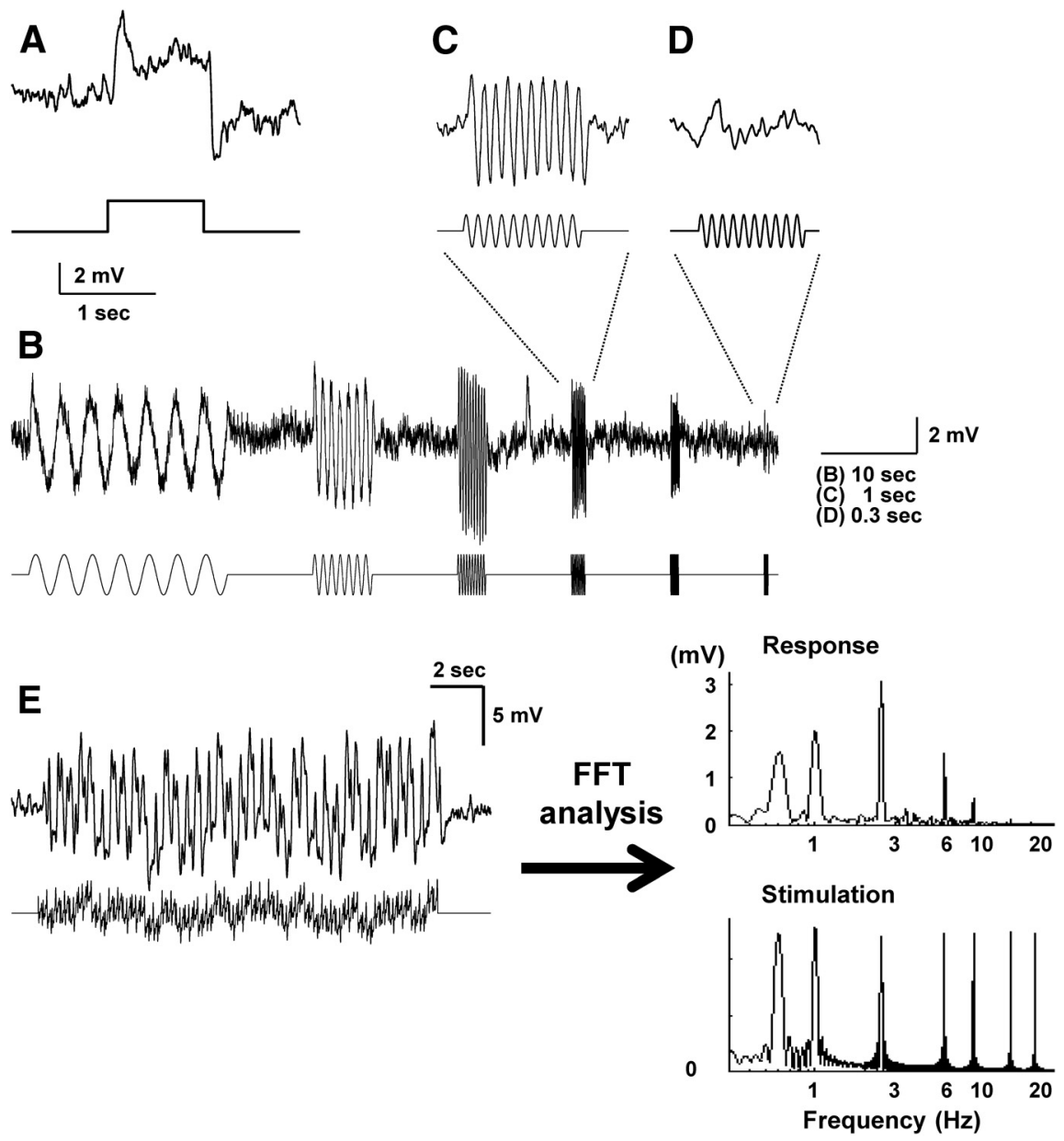

Figure 2. Experimental protocol for step-pulse stimulation and sinusoidal light stimuli. $\boldsymbol{A}$, The retinal preparation was light adapted at the level of rod saturation (Materials and Methods). A step-pulse light stimulation at $30 \%$ contrast was applied every $60 \mathrm{~s}$. Time course of a step-pulse (bottom) and sample L-EPSP trace (top). $\boldsymbol{B}$, At the same adaptation level, sinusoidal light stimuli of $0.3,1,3,6,10$, and $20 \mathrm{~Hz}$ were presented sequentially. $\boldsymbol{C}$, A sample trace of $6 \mathrm{~Hz}$ light stimuli. $\boldsymbol{D}$, A sample trace of $20 \mathrm{~Hz}$ light stimuli. $\boldsymbol{E}$, A combination of sinusoidal light stimuli $(0.15,0.6,1,2.5,6,9,15$, and $21 \mathrm{~Hz}$; bottom trace) and the response in an $0 \mathrm{~N}$ bipolar cell (top). FFT analysis revealed the temporal frequencies of sinusoidal stimuli (bottom) and voltage responses (top). The voltage responses evoked in this method were similar to the responses elicited by individual sinusoidal light stimuli.

Morphological identification. A fluorescent dye, sulforhodamine B $(0.005 \%$; Sigma $)$, was included in the pipette solution for all recordings to identify bipolar cell subtypes. Neurobiotin $(0.5 \%$; Vector Laboratories) was also included in the pipette to allow the detailed analysis of bipolar cell axon terminals. Immediately after electrophysiological recordings, sulforhodamine B images were captured using the CCD camera in the live retinal preparation. Then, the slice preparation was fixed with $4 \%$ paraformaldehyde for $30 \mathrm{~min}$, incubated with streptavidinconjugated Alexa Fluor 488 (1:200; Life Technologies) and anticalretinin antibody (1:2000; EMD Millipore) overnight at $4^{\circ} \mathrm{C}$, and then incubated with the secondary antibody for calretinin staining (antimouse Alexa Fluor 568, Life Technologies) for $2 \mathrm{~h}$ at room temperature. The slice preparation was carefully placed on a slide glass, which was sealed with an anti-fade reagent (ProLong Gold, Life Technologies) and a coverslip. The preparation was viewed with a confocal microscope (FV-1000, Olympus; or TCS SP2 or SP8, Leica). The bipolar cell subtype was determined by characterization of axon terminal ramification patterns in the inner plexiform layer (IPL; Ghosh et al., 2004; Wässle et al., 2009). For some slices, we used anti-ChAT (1:200; Millipore) in place of calretinin. Also, for some cells, synaptotagmin 2B (Syt2B; 1:200; Zirc) was used to identify subtype 6 ON bipolar cells (Wässle et al., 2009).

The IPL depth was the ratio of the distances from the inner nuclear layer (INL)/IPL border to the object and to the IPL thickness. The IPL depth was $0 \%$ if the object was on the INL/IPL border, and 100\% if it was on the IPL/ganglion cell layer. Axon terminal ramification width was measured, and the ratio against the IPL thickness was calculated.

Data analysis. For step-pulse light-evoked L-EPSPs, the amplitudes (in millivolts) of the transient and sustained components at $0.8-1.0$ $\mathrm{s}$ were measured using Clampfit software (Molecular Devices). The transient-sustained ratio was calculated as 1 - (sustained amplitude)/ (transient amplitude). The ratio is close to 1.0 for a transient response, and 0.0 for a sustained cell. The offset response was also measured at the negative peak after step-pulse stimulation relative to the sustained component of L-EPSPs.

For sinusoidal responses, Clampfit and MatLab were used to measure amplitude (in millivolts) by FFT analysis. Fundamental and multiple harmonics amplitudes were added to achieve accurate amplitude measurements. $\mathrm{Si}$ nusoidal responses were analyzed when responses were stabilized for each frequency, usually after a few cycles (Fig. 2). The troughto-trough amplitudes of L-EPSPs and L-EPSCs were normalized to the maximum responses in each cell, and converted to the decibel scale. For each cell, the response was plotted as a function of sinusoidal frequency $(0.3-20 \mathrm{~Hz})$. Cutoff responses were $-3 \mathrm{~dB}$ of the maximal response, where the energy has fallen to half of its peak. If the L-EPSP amplitude attenuated $>3 \mathrm{~dB}$ only at higher frequencies, it was categorized as a low-pass filter. If the L-EPSP amplitude attenuated $>3 \mathrm{~dB}$ both at lower and higher frequencies from its peak, it was categorized as a bandpass filter. The filter property was determined only at measured sinusoidal frequencies from 0.3 to $20 \mathrm{~Hz}$. The bandwidth was measured as the frequency $3 \mathrm{~dB}$ down points. For cells that exhibited properties near to low-pass filtering, the cutoff frequency was measured by extrapolating the frequency-response curves. The unit of bandwidth (BW) is an octave, which is calculated as $\mathrm{BW}=\log _{2}\left(f_{2} / f_{1}\right)$, where $f_{1}$ is the lower cutoff and $f_{2}$ is the higher cutoff. The bandpass-filtering nature was determined by bandwidth and the "peak frequency" of sinusoidal stimuli, which evokes the maximum amplitude of L-EPSPs for an ON bipolar cell. Values are presented as the mean \pm SEM, and differences were considered significant at $p<0.05$. Two-tailed, Student's $t$ tests were used to determine whether L-EPSPs were significant between $\mathrm{ON}$ bipolar cell subtypes.

\section{Results}

\section{ON bipolar subtype determination}

Around 13 subtypes of bipolar cells in the mouse retina have been characterized by morphological studies (Ghosh et al., 2004; Pignatelli and Strettoi, 2004; Helmstaedter et al., 2013). However, it is not well understood to what extent each subtype plays a specific role in encoding distinct images. Before characterizing the temporal tuning of each ON bipolar cell subtype, we carefully categorized the subtypes of the recorded bipolar cells by referring to the study by Wässle et al. (2009). ON bipolar cell subtypes in the mouse retina have been characterized mainly by their axon terminal ramification patterns in the IPL (Ghosh et al., 2004; Pignatelli and Strettoi, 2004). We blindly performed patch-clamp recordings from $\mathrm{ON}$ bipolar cells in $\mathrm{C} 57 \mathrm{BL} / 6 \mathrm{~J}$ mouse retinal slice preparations, injected sulforhodamine $\mathrm{B}$ and neurobiotin through 
the pipettes during physiological recordings, fixed the retinal preparation after recordings, and determined subtypes using an immunohistochemical method (Ghosh et al., 2004).

Bipolar cell axon terminals were clearly visualized by sulforhodamine B and neurobiotin injections (Fig. 1). We confirmed that neither sulforhodamine B nor neurobiotin injection during the physiological experiments affected the light responses. We recorded step light-evoked L-EPSPs in rod bipolar cells in dark-adapted retinas in the following three conditions: perforated patch-clamp; whole-cell recordings with sulforhodamine; and whole-cell recordings with both sulforhodamine and neurobiotin. L-EPSPs in response to step-pulse were $6.95 \pm 1.7 \mathrm{mV}$ ( $n=4$, perforated patch), $8.75 \pm 2.7 \mathrm{mV}(n=3$, sulforhodamine), and $8.3 \pm 1.0 \mathrm{mV}(n=5$, sulforhodamine and neurobiotin); and no differences were found among the groups $(p>$ 0.1 in any combination, unpaired $t$ test). Together, these data indicate that neither sulforhodamine nor neurobiotin affected light responses in bipolar cells.

Calretinin labels three discrete bands in the IPL. The outer and inner bands colocalize with ChAT and the mid-band divides sublaminae $\mathrm{a}$ and $\mathrm{b}$ (OFF and ON, respectively) IPLs in the mouse retina (Haverkamp and Wässle, 2000). In our data, the IPL depths of the calretinin bands were $23.9 \pm 0.8 \%, 40.1 \pm 0.7 \%$, and $56.1 \pm 1 \%(n=19$; Fig. 1$)$, which are consistent with previous reports (Ghosh et al., 2004). We also confirmed that the upper and the lower calretinin bands colocalized with ChAT bands (data not shown). Neurobiotin labeling was not always successfully attributable to weak staining or slice-handling failure after fixation. When neurobiotin labeling was unsuccessful, we determined the ON bipolar cell subtype by analyzing sulforhodamine-labeled terminal images in comparison with other bipolar cells labeled both with sulforhodamine and neurobiotin (Fig. $1 G$ ). Sulforhodamine staining was $100 \%$ successful, while neurobiotin labeling was successful $56 \%$ of the time $(24$ of $43 \mathrm{ON}$ cone bipolar cells with successful light response recordings). The IPL depth and axon terminal pattern were consistent in each subtype. All ON bipolar cells that depolarized at the onset of light stimuli ramified in the inner IPL (40-100\%). No bipolar cells ramified in both the $\mathrm{ON}$ and OFF sublaminae.

Axon terminals of subtype 5 cells ramified between midcalretinin band and inner calretinin band (ChAT band; $n=19$; Fig. $1 A-C$ ). Some branches extended on top of the ChAT band (Fig. 1A); however, they never reached out to the inner IPL. The axon terminal widths varied from narrow field (0.19) to wide field (1.07), with an average IPL thickness of $0.59 \pm 0.07$. A recent article from Helmstaedter et al. (2013) reported XBC as a separate subset from subtype 5 cells. We found similar cells with widefield axon terminals immediately next to the outer side of the ChAT band ( $n=5$; Fig. $1 C$ ). We analyzed XBCs separately throughout this study. All other subtype 5 cells ramified in the two calretinin bands, and the overall shape of the axon terminals was umbrella or triangular (Fig. $1 A, B$ ). After we analyzed physiological results, we found that two groups of subtype 5 cells with either narrow-field (Fig. 1A) or wider-field axon terminals (Fig. $1 B$ ) responded to sinusoidal light differently (described in detail below).

The ramification pattern of subtype $6 \mathrm{ON}$ bipolar cells was easily distinguished from the other subtypes. The axon terminal structure was triangle shaped, and ramified on the both outer and inner sides of the ChAT band from sublaminae 3-5, which was consistent with Syt2 immunolabeling (Fig. 1D,E; Wässle et al., 2009). The axon terminals were narrow field in the IPL with a width of $0.44 \pm 0.1$ of IPL thickness $(n=6)$. Axon terminals reached the ganglion cell layer in some cases (Fig. 1D), whereas the terminals of other cells ramified near the ChAT band (Fig. 1E).

Subtype 7 axon terminals ramified in parallel to the ChAT band, which was similar to the subtype 5 terminal ramification pattern. Subtype 5 cells ramified in the outer part of the ChAT band (S3). In contrast, all subtype 7 terminals started branching out after they crossed the ChAT band $(n=8$; Fig. $1 F)$. The majority of terminal branches stayed close to the ChAT band. Subtype 7 axon terminals were medium sized $(0.44 \pm 0.06$ of the IPL thickness).

Finally, axon terminals of subtype 8 cells were easily distinguished from other subtypes. They ramified the innermost part of the IPL and were wide field $(0.87 \pm 0.2$ of IPL thickness, $n=5$; Fig. $1 G)$. We could not identify any differences between subtypes 8 and 9 cells. Subtype 9 cells are blue cone bipolar cells (Haverkamp et al., 2005); however, all of the innermost ramifying cells we recorded responded both to green and UV light stimuli, and thus we identified them as subtype 8 cells.

\section{Temporal tuning is $\mathrm{ON}$ bipolar cell subtype dependent}

We investigated how each ON bipolar cell encoded distinct temporal visual inputs. We examined temporal encoding with the following two distinct input functions: sinusoidal light and steppulse stimuli. Sinusoidal light stimuli directly measured the temporal sensitivity of the cell from slow $(0.3 \mathrm{~Hz})$ to fast $(20 \mathrm{~Hz}$; Fig. 2). Step-pulse stimuli evoked transient and/or sustained EPSPs. Both popular methods are useful tools to characterize the temporal profile of a cell (Cruse, 2008).

We used both green $(500 \mathrm{~nm})$ and UV (360 nm) light to examine chromatic sensitivity in ON bipolar cells (Breuninger et al., 2011). In the present study, all recorded bipolar cells responded to both wavelengths similarly; thus, we analyzed only the green light-evoked responses.

Our goal was to determine how cone bipolar cells responded to cone photoreceptor inputs. To achieve this goal, we isolated the transmissions between cones and bipolar cells by blocking the lateral inhibitory inputs. We used a small spot of illumination (diameter, $100 \mu \mathrm{m}$ ), which limited the activation of both the horizontal and amacrine cells. We also included inhibitory receptor antagonists in the bath solution to block amacrine cell inputs. The cocktail of the inhibitory receptor blockers eliminated lightevoked IPSCs recorded at $0 \mathrm{mV}$ (data not shown, $n=3$ ). We also tested the effect of inhibitory receptor blockers on L-EPSPs in these conditions. Unlike previous results (Molnar and Werblin, 2007; Eggers and Lukasiewicz, 2010), these blockers did not increase the amplitude of L-EPSPs $(123 \pm 19 \% ; p=0.6 ; n=9)$ or change the temporal properties (peak frequency: no change; bandwidth: $115 \pm 10 \%$ of control solution; $p=0.2, n=9$; ON bipolar cell subtypes: $n=3$ for subtype $5 ; n=3$ for XBC; $n=1$ each for subtypes 6,7 , and 8 ), which was most likely attributable to our light stimulus conditions. We also applied background illumination at a rod-saturated level to suppress rod-signaling pathways. In this condition, both step light and sinusoidal light stimuli barely evoked light responses in rod bipolar cells $(n=23)$. Together, our recording conditions effectively isolated cone photoreceptor-cone bipolar cell transmission.

We recorded L-EPSPs to avoid disturbing any active conductance, such as voltage-gated channel activity. Whole series of sinusoidal light stimuli and step-pulse light stimuli were repeated at least three times for each cone bipolar cell, and the average responses were analyzed. L-EPSPs in response to each frequency of sinusoidal stimulation were consistent for most bipolar cell recordings. L-EPSPs were also consistent when we changed the 
A

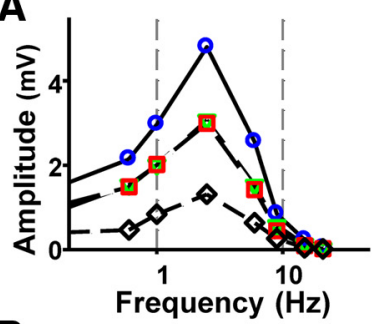

B

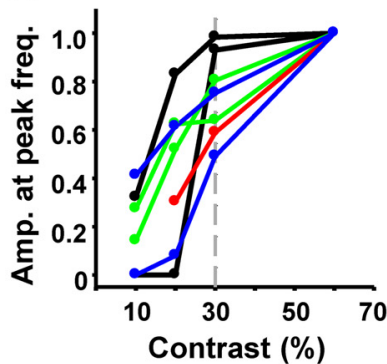

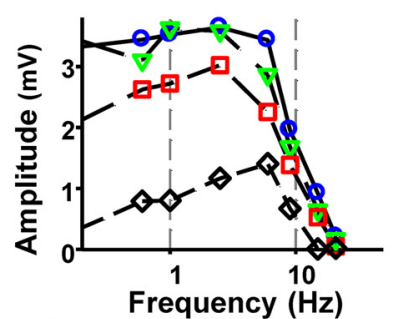

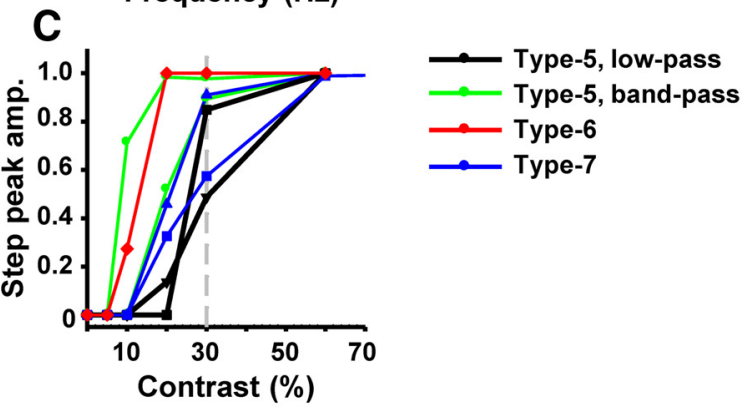

Figure 3. L-EPSPs were increased when stimulus contrast was increased; however, the temporal features did not change. $\boldsymbol{A}$ When stimulus contrast was increased, L-EPSPs were increased at most of the stimulus frequencies in a transient ON bipolar cell (left) and in a sustained ON bipolar cell (right). B , The L-EPSP amplitude at a peak frequency was plotted as a function of the stimulus contrast levels. $\boldsymbol{C}$, Higher-contrast sinusoidal stimuli evoked higher L-EPSPs in 7 ON bipolar cells. The amplitude of step light-evoked L-EPSPs were increased when contrast was increased in this range.

order of the sinusoidal frequencies $(n=4)$, suggesting that the $10 \mathrm{~s}$ interval between distinct frequencies was sufficient to recover from adaptation to previous sinusoidal stimulation paradigms (Fig. 2).

To compare the temporal properties in different subtypes of ON bipolar cells, we needed to select an appropriate stimulus contrast level. The stimulus should evoke stable L-EPSPs without saturation because a high-contrast stimulus might cause response distortion or rundown (Burkhardt et al., 2004). We tested different contrast levels using a combination of sinusoidal stimuli, which enabled us to record temporal tuning in different conditions (Fig. 2E). We found that this stimulus protocol evoked L-EPSPs similar to the ones evoked by sequential sinusoidal stimulation [Fig. $2 B$; peak frequency $2.6 \pm 0.4$ (combination proto$\mathrm{col}$ ) vs $2.8 \pm 0.2$ (sequential protocol): bandwidths $1.96 \pm 0.3$ (combination) vs $2.59 \pm 0.6$ (sequential), $p=0.3$, paired $t$ test; $n=3$ ganglion cells and $n=2$ bipolar cells].

We examined the different contrast levels from 10 to $60 \%$ (Fig. 3). The L-EPSP amplitude was continuously increased both for a bandpass-filtering bipolar cell (Fig. $3 A$, left) and for a lowpass-filtering bipolar cell (Fig. $3 A$, right). The amplitude at the peak frequency continuously increased in seven $\mathrm{ON}$ bipolar cells (Fig. $3 B$ ). However, temporal properties were consistent at these contrast levels (peak frequency and bandwidth, $p>0.1$ between different contrast levels; $n=6$ including subtypes 5,6 , and 7 cells). We chose a $30 \%$ contrast level to investigate temporal properties in ON bipolar cells because it evoked stable and subsaturated L-EPSPs. The peak amplitude of the step light-evoked L-EPSPs also increased similarly at this range of contrast changes (Fig. $3 C$ ). However, the sustained/transient ratio did not change [transient bipolar cells: $25 \pm 4 \%$ (20\% contrast), $17 \pm 2 \%(30 \%$ contrast), and $22 \pm 1 \%$ (60\% contrast), $n=3$; sustained bipolar cells: $80 \pm 8 \%$ (20\% contrast), $69 \pm 13 \%$ (30\% contrast), and $62 \pm 9 \%(60 \%$ contrast $), n=2]$. Together, the data indicate that $30 \%$ contrast light stimuli are suitable to test temporal properties in ON bipolar cells.

Sinusoidal light stimuli evoked two different patterns in ON bipolar cells. One was low-pass filtering, where the L-EPSP am-

plitude only fell $>3 \mathrm{~dB}$ at the higher frequency within a range we recorded from 0.3 to $20 \mathrm{~Hz}$. The other was bandpass filtering, where L-EPSP amplitude increased from $0.3 \mathrm{~Hz}$ to a peak frequency and then decreased at even higher frequencies. The L-EPSP amplitude of the second group fell $>3 \mathrm{~dB}$ at both the lower and higher frequencies. We did not observe high-pass filtering in any of the bipolar cells.

Both patterns were observed in subtype $5 \mathrm{ON}$ bipolar cells. We plotted the normalized amplitude of each frequency tested for all subtype 5 cells $(n=15$; Fig. $4 A$, right). One group of subtype 5 cells was low-pass filtering to sinusoidal light stimuli (Fig. 4A, right, sample traces and blue curves). Another group was bandpass filtering to sinusoidal light stimuli (Fig. 4A, right, black curves). Various temporal tuning patterns might be attributable to multiple subsets in subtype $5 \mathrm{ON}$ bipolar cells as reported previously (FykKolodziej and Pourcho, 2007; Wässle et al., 2009). We analyzed these cells to determine whether the filtering property corresponded with the morphology of the cells. The axon terminals of all subtype 5 cells ramified between the middle and inner calretinin bands; however, the extent of their terminals was diverse. Some terminals were compact $(n=8$; Fig. $1 A)$, and others were wider field ( $n=7$; Fig. $1 B$; axon terminal length, $0.40 \pm 0.1$ vs $0.73 \pm 0.1$ of IPL thickness, $p=0.009$, unpaired two-tailed $t$ test). The compact terminals were not created by retinal tissue slicing because we captured the images of all the processes deep in the tissue using confocal microscopy. Cells with compact terminal exhibited low-pass filtering, whereas cells with wider terminals exhibited bandpass filtering. The bandwidth was significantly wider in the former group than in the latter group ( $p=0.017$, unpaired two-tailed $t$ test; Table 1$)$. We named these subtypes $5 \mathrm{~s}$ (slow) and $5 \mathrm{f}$ (fast) for compact and wider cells, respectively.

XBCs were bandpass filtering to sinusoidal light stimuli ( $n=$ 5; Fig. 4B). Also, subtypes 6 and $7 \mathrm{ON}$ bipolar cells were bandpass filtering (Fig. $4 C, D$ ). However, their bandpass filtering natures were different from each other. Subtype 7 cells had the narrowest bandwidth and the highest low cutoff, indicating that they were the highest tuned cells (Table 1). XBCs were similar to subtype 7 (for bandwidth, $p=0.3$, unpaired two-tailed $t$ test), indicating that both cell types are the highest tuned ON bipolar cells. Subtype $5 \mathrm{f}$ cells were similar to XBCs; however, their bandwidth and low cutoff were slightly different from those in subtype 7 cells (bandwidth, $p=0.05$; low cutoff, $p=0.038$; unpaired two-tailed $t$ tests). Subtype 6 cells were less tuned cells compared with other bandpass cells (bandwidth: $p=0.036$ vs subtype $5 \mathrm{f} ; p=0.003$ vs $\mathrm{XBC} ; p=10^{5}$ vs subtype 7; unpaired two-tailed $t$ test). Overall, the order of the temporal tuning from high to low is subtype $7 \geq$ $\mathrm{XBCs}>$ subtype $5 \mathrm{f}>$ subtype 6 cells. Subtype 8 ON bipolar cells were low-pass filtering (Fig. $4 E$ ).

The resting membrane potential in ON bipolar cells in darkadapted conditions was $-59.3 \pm 1.3 \mathrm{mV}(n=36)$ with no significant differences among subtypes. Temporal features might be affected by different temperature settings. Most of our recordings were performed at $30^{\circ} \mathrm{C}$. We examined whether sinusoidal light- 
$0.3 \mathrm{~Hz}$

$3 \mathrm{~Hz}$

$6 \mathrm{~Hz}$

$10 \mathrm{~Hz}$

A T-5
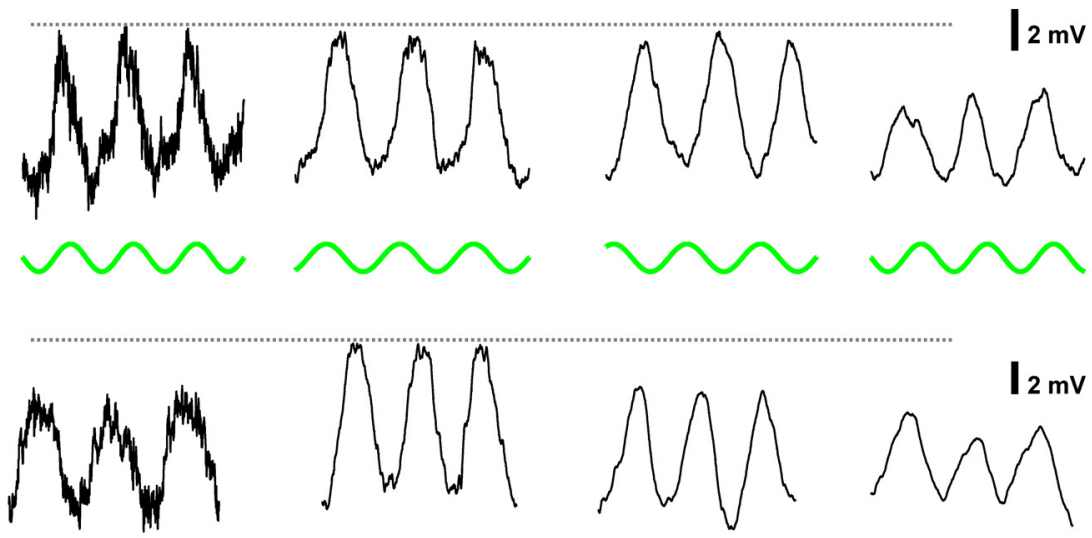

Вхвс $N^{m}$
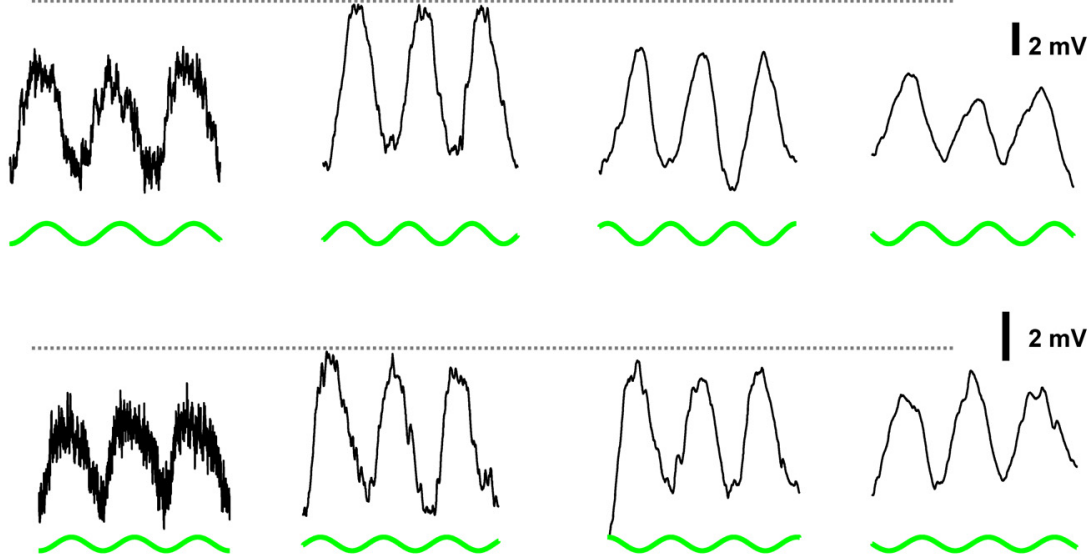

C T-6
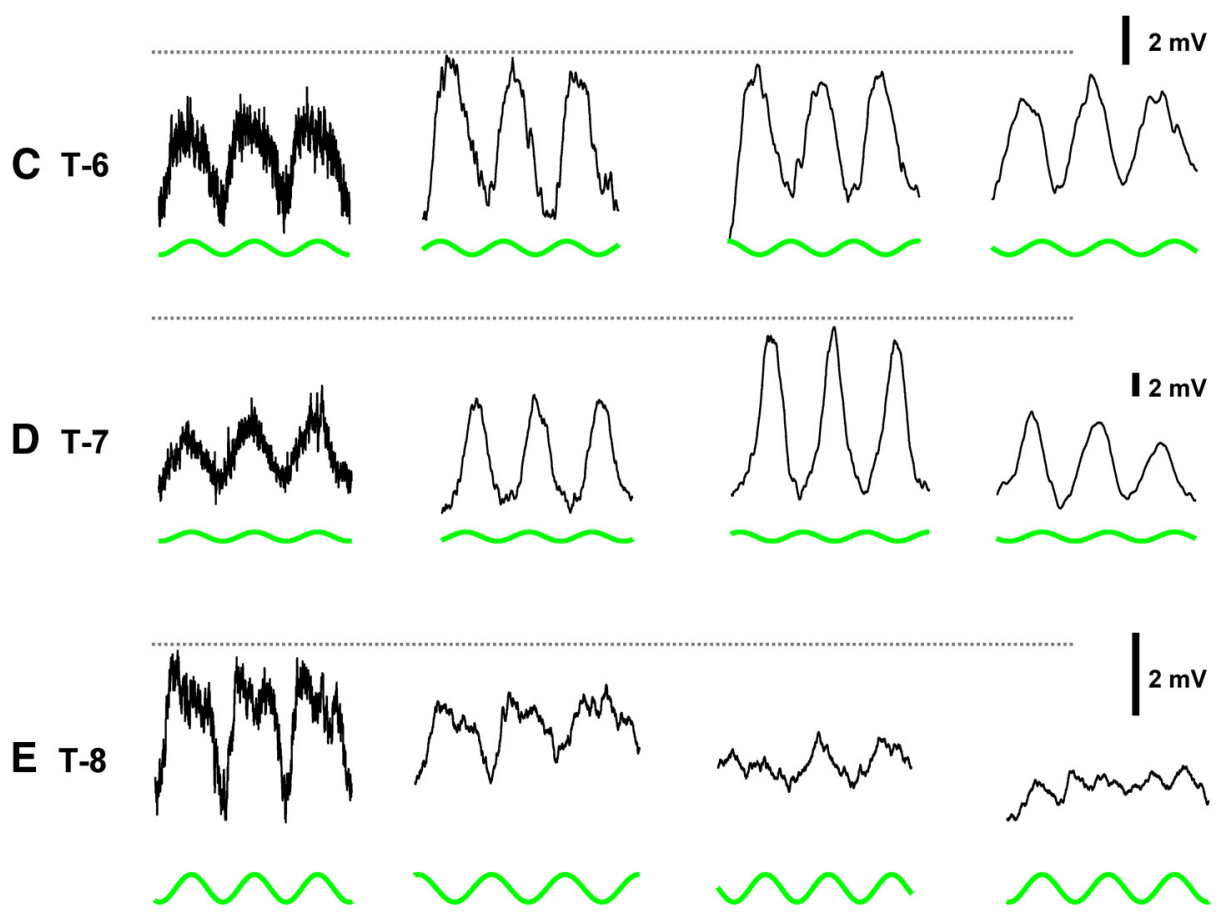
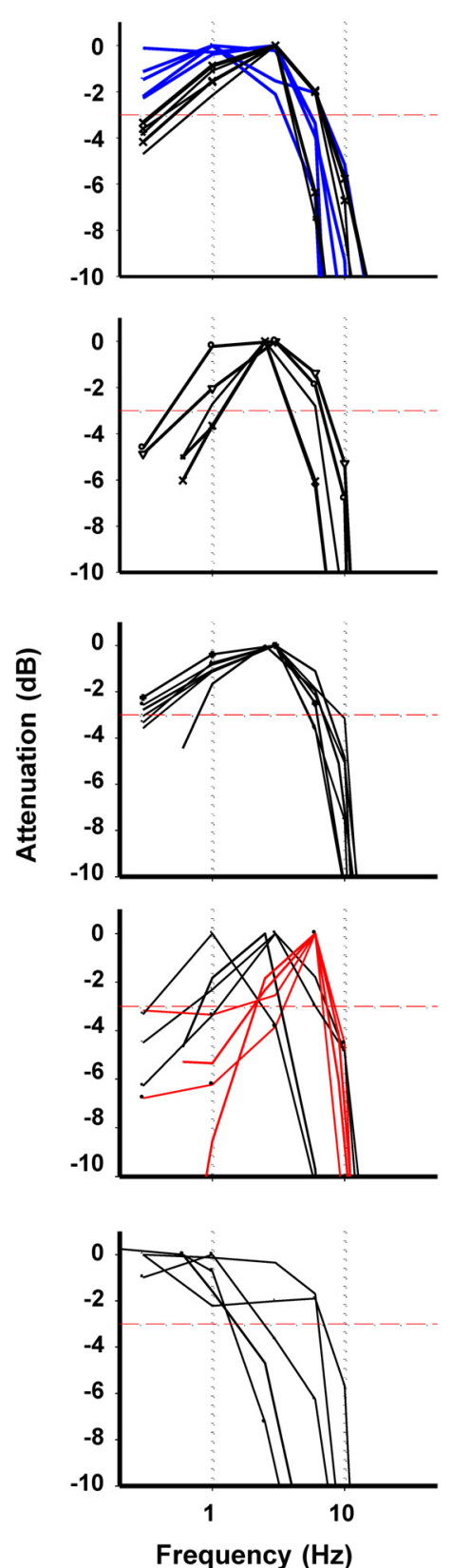

Figure 4. EPSPs elicited by sinusoidal light stimuli were $0 \mathrm{~N}$ bipolar cell subtype specific. $A$, Subtype $5 \mathrm{~s} 0 \mathrm{~N}$ bipolar cells were near-low-pass filtering ( $n=8$, blue curves), whereas subtype $5 \mathrm{f}$ cells were bandpass filtering ( $n=7$, black curves). $\boldsymbol{B}$, XBCs were bandpass filtering $(n=6)$. C, Subtype 6 cells were bandpass filtering $(n=7)$. D , Subtype 7 cells were bandpass filtering with narrow bandwidths. A group of cells exhibited particularly narrow bandwidths compared with another subset of subtype 7 cells $(p<0.05)$; however, no differences were found between these groups in terms of transient/sustained ratio, high cutoff, or offshoot amplitude. The former group of cells is plotted in red $(n=4)$, whereas the latter group of cells is shown in black ( $n=4$ ). $\boldsymbol{E}$, Subtype 8 cells were low-pass filtering $(n=5)$.

Table 1. ON bipolar cell L-EPSPs in response to sinusoidal and step light stimuli

\begin{tabular}{|c|c|c|c|c|c|c|}
\hline Subtypes & $\begin{array}{l}\text { Type 5s } \\
(n=8)\end{array}$ & $\begin{array}{l}\text { Type 5f } \\
(n=7)\end{array}$ & $\begin{array}{l}\mathrm{XBC} \\
(n=5)\end{array}$ & $\begin{array}{l}\text { Type } 6 \\
(n=6)\end{array}$ & $\begin{array}{l}\text { Type 7 } \\
(n=8)\end{array}$ & $\begin{array}{l}\text { Type } 8 \\
(n=5)\end{array}$ \\
\hline Filtering & Low-pass to bandpass & Bandpass & Bandpass & Bandpass & Bandpass & Low-pass \\
\hline Low cutoff $(\mathrm{Hz})$ & $0.19 \pm 0.05$ & $0.56 \pm 0.1$ & $0.83 \pm 0.1$ & $0.34 \pm 0.02$ & $1.63 \pm 0.4$ & $0.01^{*}$ \\
\hline High cutoff (Hz) & $5.21 \pm 0.5$ & $4.88 \pm 0.5$ & $5.79 \pm 0.7$ & $7.12 \pm 0.6$ & $6.34 \pm 0.8$ & $3.78 \pm 1.5$ \\
\hline Bandwidth $(\mathrm{Hz})$ & $5.29 \pm 0.6$ & $3.33 \pm 0.4$ & $2.84 \pm 0.4$ & $4.57 \pm 0.2$ & $2.23 \pm 0.3$ & $8.98 \pm 0.5$ \\
\hline Transient/sustained ratio & $0.53 \pm 0.06$ & $0.69 \pm 0.03$ & $0.68 \pm 0.02$ & $0.61 \pm 0.04$ & $0.77 \pm 0.03$ & $0.36 \pm 0.07$ \\
\hline OFF overshoot (mV) & $0.84 \pm 0.1$ & $2.32 \pm 0.5$ & $2.23 \pm 0.5$ & $2.66 \pm 0.2$ & $2.98 \pm 0.7$ & $0.94 \pm 0.2$ \\
\hline
\end{tabular}

Data are presented as the mean \pm SEM.

*All type-8 cells were low-pass filtering feature. Low cut-off was determined as the lowest frequency among all other bipolar cells. 


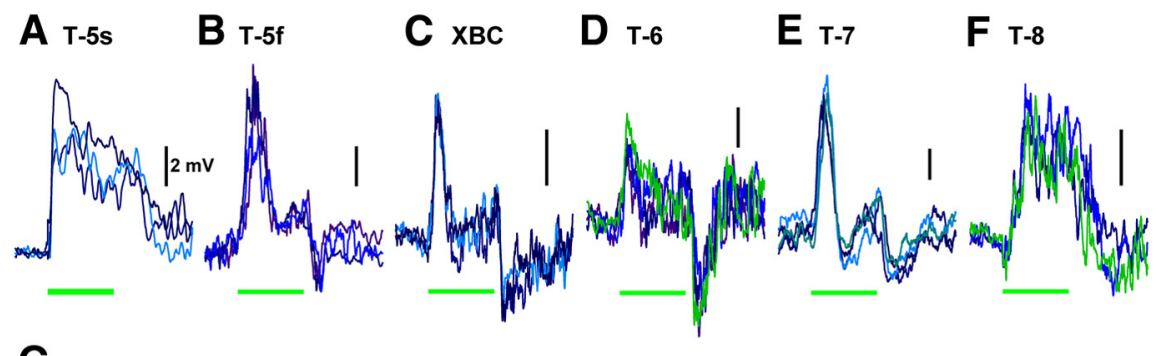

G

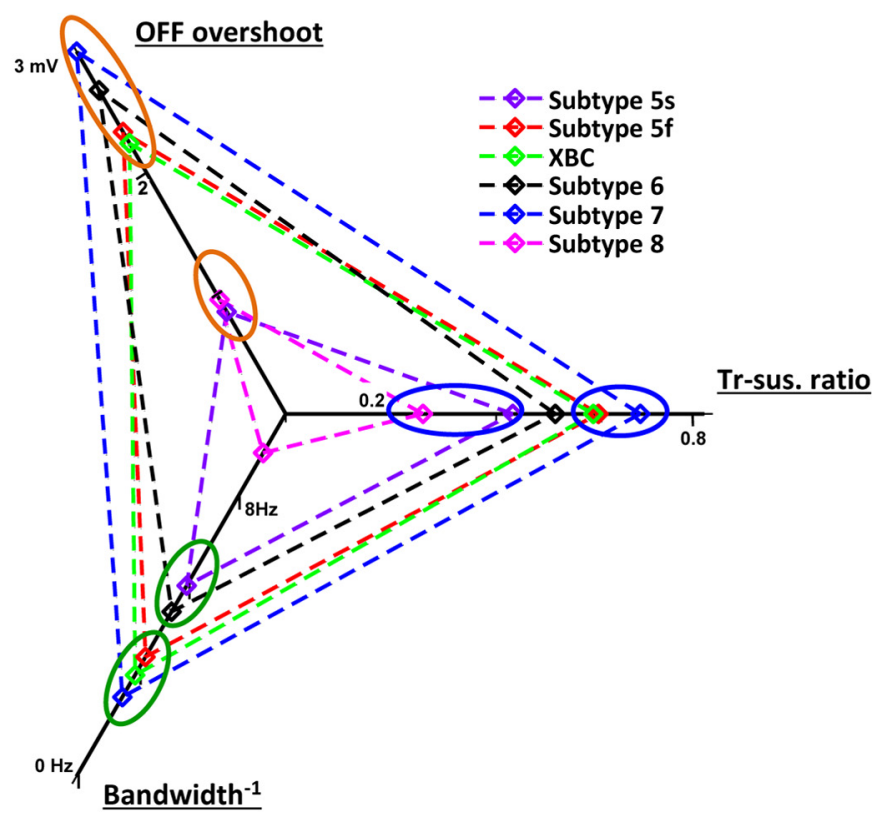

Figure 5. Transient and sustained responses to step-pulse light stimuli were also $0 \mathrm{~N}$ bipolar cell subtype specific. $\boldsymbol{A}-\boldsymbol{F}$, Steppulse light stimuli of $30 \%$ contrast evoked L-EPSPs in subtype $5 \mathrm{~s}(\boldsymbol{A})$, subtype $5 f(\boldsymbol{B}), \mathrm{XBC}(\boldsymbol{C})$, subtype $6(\boldsymbol{D})$, subtype $7(\boldsymbol{E})$, and subtype $80 \mathrm{~N}$ bipolar cells $(\boldsymbol{F})$. Three to six traces were overlaid from a representative cell in each subtype. $\boldsymbol{G}$, A summary plot shows three temporal analysis parameters for $60 \mathrm{~N}$ bipolar cell subtypes. For all parameters, temporal tuning is higher from the rear to the front of each axis. Subtypes in a circle were not significantly different from each other. All parameters in subtype 7 cells were the highest, indicating that these cells were highly tuned to a temporal frequency. Conversely, subtype 8 cells were the most sustained cells.

evoked L-EPSPs changed when the recordings were performed at $35-37^{\circ} \mathrm{C}$, which is near the mouse body temperature $\left(\sim 37^{\circ} \mathrm{C}\right.$; Habicht, 1981). We recorded the temporal frequency at $30^{\circ} \mathrm{C}$ before the bath temperature was increased to a new target temperature. When the temperature was increased, higher-frequency L-EPSPs were also increased $(261 \pm 105 \%$ at $6 \mathrm{~Hz}$, range $121-$ $889 \%, n=7, p=0.02$, paired $t$ test). However, the peak frequency $(92 \pm 8 \%)$ and bandwidth (104 $\pm 7 \%)$ did not change ( $n=7, p>0.1$, paired $t$ test). Therefore, our temporal property data determined at $30^{\circ} \mathrm{C}$ are likely relevant to the data obtained at physiological temperatures.

\section{Step pulse-evoked L-EPSPs were also tuned in a subtype-dependent manner}

We next tested temporal encoding using step-pulse light stimuli. The transient and sustained response dichotomy has been known for many decades; it can be observed in different temporal visual processing cells (Enroth-Cugell and Robson, 1966; Cleland et al., 1971) and is thought to be the hallmark of temporal visual signaling. A transient and sustained response dichotomy also exists in retinal bipolar cells and is thought to be the origin of parallelprocessing pathways (Awatramani and Slaughter, 2000; DeVries, 2000; Euler and Masland, 2000). However, it is not known how it relates to bipolar cell subtypes. To address this, we used $1 \mathrm{~s}$ step- pulse light stimuli to evoke transient and/or sustained L-EPSPs in ON cone bipolar cells.

Step light-evoked EPSPs were also ON bipolar cell subtype specific. L-EPSPs in subtypes $5 \mathrm{~s}$ and 8 were sustained, whereas subtypes $5 \mathrm{f}, 6,7$, and $\mathrm{XBC}$ were transient (Fig. 5A-F). We analyzed their transientsustained features by measuring their peaks and plateau amplitudes (at $0.8 \mathrm{~s}$; Table 1). The transient/sustained ratio was the highest in subtype 7 cells, which was similar to the ratios in subtypes $5 \mathrm{f}$ and XBC cells ( $p>0.1$, unpaired two-tailed $t$ test). The ratio was significantly lower in subtype 6 cells ( $p=0.008$ vs subtype 7 , unpaired two-tailed $t$ test). The transient/ sustained ratio in subtypes 8 and $5 \mathrm{~s}$ was lower than that in other transient cells ( $p<0.01$ vs subtypes $5 f, 6,7$, and XBC; $p=0.08$ between subtypes 5 s and 8 , unpaired two-tailed $t$ test).

In some cells, the offset light response was prominent, which might be attributable to "OFF overshoot" from cone terminals (Jackman et al., 2009). We measured the offset amplitude and found that it was also ON bipolar cell subtype dependent (Table 1). In subtypes 5f, 6, 7, and XBC ON bipolar cells, the OFF overshoot clearly existed, whereas it was barely observed in subtypes $5 s$ and $8(p<0.01$, between two groups, unpaired two-tailed $t$ test).

Finally, we compared the results of the two input functions in each ON bipolar cell subtype. We plotted the transient/sustained ratio, bandwidth, and OFF overshoot amplitude for each subtype along three axes (Fig. 5G). The transient/sustained ratio is lower toward the center and higher toward the outer edge of the plot. The degree of bandwidth is lower toward the center and higher toward the edge of the plot, showing narrower bandpass feature toward the edge of the axis. The OFF overshoot amplitude is lower toward the center and higher toward the edge of the plot. For each ON bipolar cell subtype, the mean value was plotted and connected among three parameters (Table 1). For each parameter, subtypes are circled if they were not statistically different from each other $(p>0.1)$. For all parameters, subtype 7 was the most transient cell type, whereas subtype 8 was the most sustained cell type. XBC and subtype $5 \mathrm{f}$ cells were similar to subtype 7 cells (for the ratio and OFF overshoot, $p>0.1$ among three subtypes; for bandwidth: $p=0.3$ for subtype 7 vs XBC; $p=0.05$ for subtype 7 vs subtype 5f; $p=0.4$ for XBC vs subtype 5f; unpaired $t$ test). Subtype $5 \mathrm{~s}$ cells were similar to subtype 8 cells (for the ratio and the OFF overshoot, $p=0.7$; for bandwidth, $p=$ 0.05 ; unpaired $t$ test). Subtype 6 cells were between these groups (for the ratio: $p=0.008$ vs subtype $7 ; p=0.006$ vs subtype 8 ; for bandwidth: $p=0.03$ vs subtype 5f; $p<0.01$ vs XBC and subtype $7, p=10^{-5}$ vs subtype 8 ; for OFF overshoot: $p<0.001$ vs subtypes $5 \mathrm{~s}$ and 8 ; unpaired $t$ test).

Based on this analysis, we conclude that subtype 7 cells are the most change-sensitive cells along with XBCs. Subtype $5 \mathrm{f}$ cells are 
similar to XBCs. On the contrary, subtype 8 cells are the most sustained cells, followed by subtype 5 s cells, which might be responsible for detecting static objects. Subtype 6 cells exhibit properties that are between these two groups. Therefore, our results confirm that $\mathrm{ON}$ cone bipolar cells encode distinct temporal visual inputs in a subtype-dependent manner.

Search for underlying mechanisms of ON bipolar cell response diversity

Our results indicated that temporal encoding in ON cone bipolar cells was subtype specific. Because we isolated the transmission between photoreceptors and $\mathrm{ON}$ bipolar cells, the response diversity most likely occurs by signal modulation within ON bipolar cells. Heterogeneous expression of voltage-gated channels has been reported (Connaughton and Maguire, 1998; Pan and Hu, 2000; Pan, 2000; Ichinose et al., 2005; Cangiano et al., 2007) and might contribute to subtype-dependent temporal tuning in $\mathrm{ON}$ bipolar cells.

We first examined photoreceptor inputs without activating voltage-gated channels in bipolar cells. We recorded L-EPSCs in response to the sinusoidal light stimuli using the voltage-clamp mode (Fig. 6). L-EPSCs in response to sinusoidal light stimuli were bandpass filtering for all subtypes of ON bipolar cells. Even for cells with low-pass-filtering L-EPSPs, L-EPSCs were bandpass filtering (Fig. $6 B$, subtype $5 \mathrm{~s}, G$, subtype 8 ). This indicates that the photoreceptor inputs in $\mathrm{ON}$ bipolar cells are bandpass filtering in nature, which is consistent with previous findings in the rod pathway (Armstrong-Gold and Rieke, 2003).

We then investigated the role of voltage-gated channels by recording voltage changes in response to sinusoidal current injection. We used the same stimulus protocol as that used for sinusoidal light stimulation (Fig. 2). We injected current at 1-2 $\mathrm{pA}$, which evoked amplitudes of sinusoidal responses similar to L-EPSPs at $0.3 \mathrm{~Hz}$ (compare Figs. 7A, 4A). Responses to sinusoidal current injection were low-pass filtering in all tested $\mathrm{ON}$ bipolar cells (Fig. 7B). This was also the case in cells that responded to light stimuli in a bandpass fashion; responses to current injection were low-pass filtering in nature (Fig. $7 C$, subtype $6, D$, subtype 7). These results indicate that bipolar cells are intrinsically low-pass filtering, and that photoreceptor inputs are bandpass filtering in nature.

Together, our results indicate that ON bipolar cells can be divided into three groups. The first is subtype 6 , which are passive ON bipolar cells. L-EPSCs and L-EPSPs were similar in these cells (bandwidth, 4.93; $p=0.3$ vs L-EPSP in subtype 6, unpaired $t$ test; Fig. $6 E$ ), suggesting that visual signaling from photoreceptors is passively encoded. In the second group, subtypes $5 \mathrm{~s}$ and 8 are sustained cells with low-pass filtering properties. Because sinusoidal current evoked low-pass filtering responses (Fig. 7) and L-EPSCs were still of a bandpass filtering nature in these cells, voltage-gated channels might robustly contribute to the sus- tained responses. The third group, which is composed of subtypes 7, 5f, and XBC ON bipolar cells, is transient. Although current-evoked responses were low-pass filtering (Fig. 7D), L-EPSCs were not overlaid with L-EPSPs (Fig. $6 C, D, F$ ), suggesting that multiple mechanisms including voltage-gated channels contribute to shape their bandpass-filtering nature.

\section{Discussion}

Diverse visual signal-processing pathways start at the retinal bipolar cell level (Awatramani and Slaughter, 2000; DeVries, 2000; Wässle, 2004). Several subtypes of ON cone bipolar cells have been identified by morphological studies in the mouse retina (Ghosh et al., 2004; Wässle et al., 2009); however, except for blue cone bipolar cells (Haverkamp et al., 2005), the functions of ON bipolar cells remain poorly understood. In the present study, we characterized the visually evoked temporal properties along with the morphology of six subtypes of ON bipolar cells for the first time in the mouse retina.

\section{Bipolar cell subtypes and functions}

Morphological studies have revealed $>10$ subtypes of bipolar cells in the mouse retina (Ghosh et al., 2004; Pignatelli and Strettoi, 2004), rat retina (Euler and Wässle, 1995), primate retina (Boycott and Wässle, 1991), rabbit retina (MacNeil et al., 2004), 


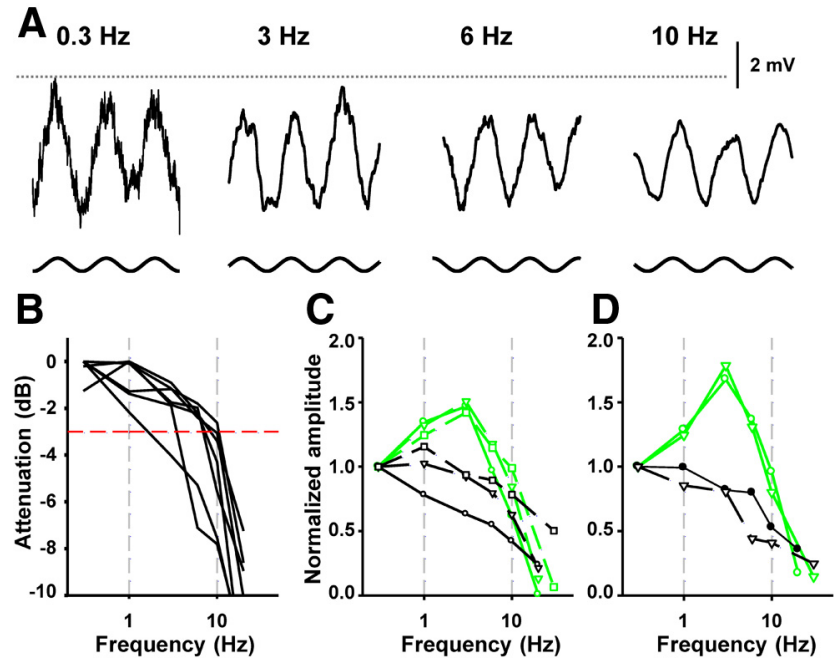

Figure 7. Responses to current injection were low-pass filtering in 0 N bipolar cells. $\boldsymbol{A}$, Sinusoidal current injection evoked responses, which were reduced as the frequency increased. $\boldsymbol{B}$, Sinusoidal current-evoked responses were always low-pass filtering $(n=7)$. C, Subtype $60 \mathrm{~N}$ bipolar cells. L-EPSPs were bandpass filtering (green), whereas current responses were lowpass filtering (black) in the same cells. D, Subtype $70 \mathrm{~N}$ bipolar cells. Similarly, L-EPSPs (green) were bandpass filtering, whereas responses to current injection (black) were low-pass filtering in the same cells.

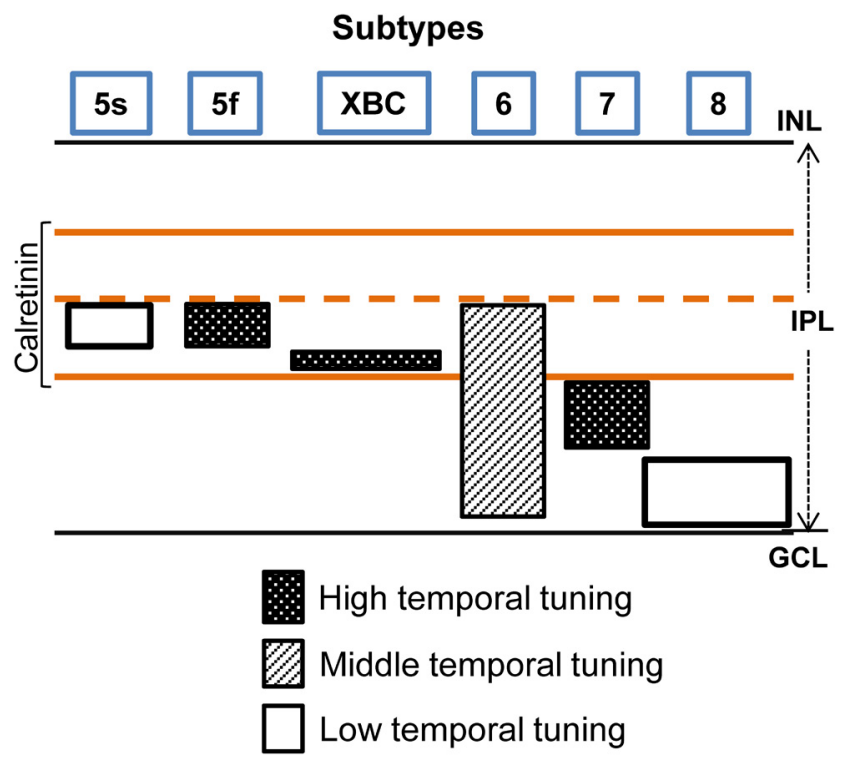

Figure 8. Summary diagram of the $0 \mathrm{~N}$ cone bipolar cell contribution to temporal processing. ON cone bipolar cells encode distinct temporal visual signaling in a subtype-dependent manner. In most of the IPL sublamina b, both high and low temporal bipolar cells provide synaptic outputs. Subtypes 7 and XBC are especially highly tuned to particular frequencies that provide synaptic outputs near the ChAT band.

and salamander retina (Wu et al., 2000). Wässle et al. (2009) used subtype-specific markers and concluded that there are 11 subtypes of cone bipolar cells in the mouse retina (types 1 through 9 with two subsets of types 3 and 5). Multiple subsets of subtype 5 cells have been described (Ghosh et al., 2004; Fyk-Kolodziej and Pourcho, 2007). Recently, Helmstaedter et al. (2013) used connectomic reconstruction analysis to identify the XBC subtype in sublamina 3 of the IPL, which is distinct from the other kinds of subtype 5 cells. Similarly, our morphological and physiological analyses also revealed three subsets of ON bipolar cells in sublamina 3: subtypes 5s, 5f, and XBC. Therefore, a total of 13 sub- types of bipolar cells, including rod bipolar cells, have been identified in the mouse retina. Each subtype of bipolar cell is thought to contribute to visual signaling in a distinct way.

Functions of each bipolar cell subtype have been studied. Light sensitivity varies among subsets of ON cone bipolar cells, which is attributable to the mixed inputs from rods and cones (Pang et al., 2004, 2010). The effect of surround inhibition on visual signaling is diverse among bipolar cell subsets (Molnar and Werblin, 2007; Zhang and Wu, 2009). Chromatic responses have been shown to be bipolar cell subtype dependent (Haverkamp et al., 2005; Breuninger et al., 2011).

The diversity of temporal tuning has also been investigated. Transient and sustained light responses were found in distinct subsets of $\mathrm{ON}$ bipolar cells in salamander and rat retinas (Awatramani and Slaughter, 2000; Euler and Masland, 2000). Three subtypes of OFF cone bipolar cells in the ground squirrel retina tune distinctively (DeVries, 2000; DeVries et al., 2006). Recently, bipolar cell temporal processing has been characterized with imaging studies. Calcium signals at bipolar axon terminals (Baden et al., 2013) and glutamate sensor imaging (iFluSnFR) throughout the IPL (Borghuis et al., 2013) revealed the detailed transient/ sustained features in the IPL. In the present study, we performed whole-cell recordings from individual bipolar cells and found that temporal processing occurs in these cells in a subtypedependent manner. Specifically, we found that XBCs are highly tuned cells along with subtype 7 and $5 \mathrm{f} \mathrm{ON} \mathrm{bipolar} \mathrm{cells.} \mathrm{In} \mathrm{con-}$ trast, subtype 8 and $5 \mathrm{~s}$ cells exhibit a low-pass-filtering feature. Subtype 6 cells show properties of both groups.

\section{Distinct temporal filtering mechanisms}

In the present study, we isolated photoreceptor-ON bipolar cell transmission from the rest of the retinal network; thus, the observed diversity in responses is likely attributable to signal modulation within ON bipolar cells. Diverse temporal encoding in OFF bipolar cells occurs by distinct ionotropic glutamate receptors in their dendrites (DeVries, 2000). ON bipolar cells receive synaptic inputs from photoreceptors via the metabotropic glutamate receptor 6 (mGluR6). mGluR6-linked cation channels were recently identified (Morgans et al., 2009; Shen et al., 2009; Koike et al., 2010). The diversity of mGluR6 has been suggested by Awatramani and Slaughter (2000); however, molecular biological evidence has not been provided. Preliminary work with lowpass-filtering ON bipolar cells $(n=2)$ converted to bandpass filtering in the presence of a low dose of mGluR6 agonist (L-AP4, $1.6 \mu \mathrm{M}$ ) suggests that the state of mGluR6 is critical to the filtering process (data not shown). Further experimental studies are required to expand this preliminary work on the mechanisms of distinct filtering in ON bipolar cells.

Voltage-gated channels represent another key candidate modulator for signaling diversity in ON bipolar cells. In the present study, all photoreceptor inputs (L-EPSCs) were bandpass filtering; however, L-EPSPs were diverse (Fig. 6). Because current injection sinusoidal responses were low-pass filtering (Fig. 7), voltage-gated channels might play a key role. For example, HCN channels suppressed lower-frequency responses to shape bandpass filtering in rod bipolar cells (Cangiano et al., 2007). HCN channels are expressed in cone bipolar cells (Ma et al., 2003; Puthussery et al., 2013) and might contribute to shaping sustained responses in some bipolar cells.

In contrast, the voltage responses (L-EPSPs) of subtype 7 and XBC bipolar cells exhibited slightly narrower bandpass features than L-EPSCs (Fig. 6). These cells might be tuned by excitatory modulation via $\mathrm{Ca}^{2+}$ channels and/or $\mathrm{Na}^{+}$channels because 
voltage-gated $\mathrm{Na}^{+}$channels enhance temporal filtering in fish sensory neurons (Fortune and Rose, 1997, 2003) and are heterogeneously expressed among bipolar cells (Pan and $\mathrm{Hu}, 2000$; Pan, 2000; Pan et al., 2001; Zenisek et al., 2001; Ichinose et al., 2005; Saszik and DeVries, 2012; Puthussery et al., 2013). Especially, spiking activity in some bipolar cells might be a key mechanism for fast temporal tuning (Cui and Pan, 2008; Saszik and DeVries, 2012; Puthussery et al., 2013), although we did not find spiking activity probably because our pipette solution did not contain creatine phosphate (Baden et al., 2011).

\section{Roles of retinal ON bipolar cells in visual signal processing}

Bipolar cells are called "relay cells" because they pass on visual signals from photoreceptors to the retinal output neurons, ganglion cells. Our results indicate that they dynamically relay visual signaling. Cone photoreceptors in the mouse retina are low-pass filtering with a peak of $5-6 \mathrm{~Hz}$ and a cutoff frequency of $\sim 10 \mathrm{~Hz}$ (Burkhardt et al., 2007; Qian et al., 2008). In the present study, we found that cone inputs in bipolar cells are bandpass filtering with a peak of $3-6 \mathrm{~Hz}$ (Fig. $6 B$ ), suggesting that there is a mechanism modulating the signal between photoreceptor output and bipolar cell encoding. "OFF overshoot" is the light offset response at the cone photoreceptor terminals, which enables phasic transmitter release by tonic-responding photoreceptors (Jackman et al., 2009). Because of its regenerative nature ( $\mathrm{Wu}, 1988)$, the OFF overshoot might be responsible for this conversion from lowpass filtering in cones to bandpass filtering in bipolar cells. Consistent with this notion, OFF overshoot was clearly detected in bandpass-filtering bipolar cells (Fig. 5).

How do bipolar cells contribute to temporal processing in ganglion cells and at higher levels? It is assumed that low-passfiltering bipolar cells contribute to linear ganglion cells, whereas bandpass-filtering bipolar cells contribute to nonlinear and dynamic ganglion cells. Detailed subtyping of ganglion cells has been revealed only recently (Völgyi et al., 2009; Sümbül et al., 2014), and the elucidation of synaptic architecture between bipolar and ganglion cells awaits future experiments. Several mechanisms functioning between bipolar and ganglion cells have been suggested. One is the amacrine cell feedback, which shapes visual signaling in bipolar cells (Dong and Hare, 2002; Eggers and Lukasiewicz, 2006). Another mechanism is the frequency-doubled response, which occurs at the synapses between bipolar and ganglion cells (Demb et al., 1999; Borghuis et al., 2013).

Figure 8 summarizes how ON bipolar cells might contribute to temporal processing. Interestingly, because of their terminal ramification patterns, both high and low temporal tuned signaling can be transferred to ganglion cells in most of the ON sublaminae in the IPL. This is consistent with the ganglion cell ramification patterns, which ramify in most layers of the IPL (Sümbül et al., 2014). Subtype 7 and XBC ON bipolar cells demonstrated the highest temporal profiles (Fig. 5, Table 1) and axons from these cells ramify very close to the ChAT band, suggesting that these cells provide fast visual signaling to the directionselective (DS) cells and thus contribute to motion detection. Such a hypothesis is consistent with an article by Yonehara et al. (2013), which identified subtype 5- and also 7-like ON bipolar cells, providing synaptic inputs to DS ganglion cells. Subtype 6 cells demonstrated a passive feature that might be similar to midget bipolar cells in the primate retina (Puthussery et al., 2013).

In conclusion, we investigated temporal encoding in six subtypes of ON cone bipolar cells in the mouse retina. For the first time, we were able to analyze temporal frequency and transientsustained light responses, occurring at the dendrites to the soma, in a subtype-specific manner. We believe that our results will contribute to the elucidation of parallel processing in the visual system.

\section{References}

Armstrong-Gold CE, Rieke F (2003) Bandpass filtering at the rod to secondorder cell synapse in salamander (Ambystoma tigrinum) retina. J Neurosci 23:3796-3806. Medline

Awatramani GB, Slaughter MM (2000) Origin of transient and sustained responses in ganglion cells of the retina. J Neurosci 20:7087-7095. Medline

Baden T, Esposti F, Nikolaev A, Lagnado L (2011) Spikes in retinal bipolar cells phase-lock to visual stimuli with millisecond precision. Curr Biol 21:1859-1869. CrossRef Medline

Baden T, Berens P, Bethge M, Euler T (2013) Spikes in mammalian bipolar cells support temporal layering of the inner retina. Curr Biol 23:48-52. CrossRef

Berntson A, Taylor WR (2000) Response characteristics and receptive field widths of on-bipolar cells in the mouse retina. J Physiol 524:879-889. CrossRef Medline

Borghuis BG, Marvin JS, Looger LL, Demb JB (2013) Two-photon imaging of nonlinear glutamate release dynamics at bipolar cell synapses in the mouse retina. J Neurosci 33:10972-10985. CrossRef Medline

Boycott BB, Wässle H (1991) Morphological classification of bipolar cells of the primate retina. Eur J Neurosci 3:1069-1088. CrossRef Medline

Breuninger T, Puller C, Haverkamp S, Euler T (2011) Chromatic bipolar cell pathways in the mouse retina. J Neurosci 31:6504-6517. CrossRef Medline

Burkhardt DA, Fahey PK, Sikora MA (2004) Retinal bipolar cells: contrast encoding for sinusoidal modulation and steps of luminance contrast. Vis Neurosci 21:883-893. CrossRef Medline

Burkhardt DA, Fahey PK, Sikora MA (2007) Retinal bipolar cells: temporal filtering of signals from cone photoreceptors. Vis Neurosci 24:765-774. CrossRef Medline

Cangiano L, Gargini C, Della Santina L, Demontis GC, Cervetto L (2007) High-pass filtering of input signals by the Ih current in a non-spiking neuron, the retinal rod bipolar cell. PLoS One 2:e1327. CrossRef Medline

Cleland BG, Dubin MW, Levick WR (1971) Sustained and transient neurones in the cat's retina and lateral geniculate nucleus. J Physiol 217:473496. Medline

Connaughton VP, Maguire G (1998) Differential expression of voltagegated $\mathrm{K}+$ and $\mathrm{Ca} 2+$ currents in bipolar cells in the zebrafish retinal slice. Eur J Neurosci 10:1350-1362. CrossRef Medline

Cruse H (2008) Neural networks as cybernetic systems. In: Brains, mids and media, Ed3 (Cruse H, ed). Bielefeld, Germany: Department of Biological Cybernetics and Theoretical Biology, Bielefeld University. E-book available at http://www.brains-minds-media.org/archive/1841.

Cui J, Pan ZH (2008) Two types of cone bipolar cells express voltage-gated $\mathrm{Na}+$ channels in the rat retina. Vis Neurosci 25:635-645. CrossRef Medline

Dacey DM, Peterson BB, Robinson FR, Gamlin PD (2003) Fireworks in the primate retina: in vitro photodynamics reveals diverse LGN-projecting ganglion cell types. Neuron 37:15-27. CrossRef Medline

Demb JB, Haarsma L, Freed MA, Sterling P (1999) Functional circuitry of the retinal ganglion cell's nonlinear receptive field. J Neurosci 19:97569767. Medline

DeVries SH (2000) Bipolar cells use kainate and AMPA receptors to filter visual information into separate channels. Neuron 28:847-856. CrossRef Medline

DeVries SH, Li W, Saszik S (2006) Parallel processing in two transmitter microenvironments at the cone photoreceptor synapse. Neuron 50:735748. CrossRef Medline

Dong CJ, Hare WA (2002) GABAc feedback pathway modulates the amplitude and kinetics of ERG b-wave in a mammalian retina in vivo. Vision Res 42:1081-1087. CrossRef Medline

Eggers ED, Lukasiewicz PD (2006) GABA(A), GABA(C) and glycine receptor-mediated inhibition differentially affects light-evoked signalling from mouse retinal rod bipolar cells. J Physiol 572:215-225. CrossRef Medline

Eggers ED, Lukasiewicz PD (2010) Interneuron circuits tune inhibition in retinal bipolar cells. J Neurophysiol 103:25-37. CrossRef Medline 
Enroth-Cugell C, Robson JG (1966) The contrast sensitivity of retinal ganglion cells of the cat. J Physiol 187:517-552. Medline

Euler T, Masland RH (2000) Light-evoked responses of bipolar cells in a mammalian retina. J Neurophysiol 83:1817-1829. Medline

Euler T, Wässle H (1995) Immunocytochemical identification of cone bipolar cells in the rat retina. J Comp Neurol 361:461-478. CrossRef Medline

Fortune ES, Rose GJ (1997) Passive and active membrane properties contribute to the temporal filtering properties of midbrain neurons in vivo. J Neurosci 17:3815-3825. Medline

Fortune ES, Rose GJ (2003) Voltage-gated Na + channels enhance the temporal filtering properties of electrosensory neurons in the torus. J Neurophysiol 90:924-929. CrossRef Medline

Fyk-Kolodziej B, Pourcho RG (2007) Differential distribution of hyperpolarization-activated and cyclic nucleotide-gated channels in cone bipolar cells of the rat retina. J Comp Neurol 501:891-903. CrossRef Medline

Ghosh KK, Bujan S, Haverkamp S, Feigenspan A, Wässle H (2004) Types of bipolar cells in the mouse retina. J Comp Neurol 469:70-82. CrossRef Medline

Habicht GS (1981) Body temperature in normal and endotoxin-treated mice of different ages. Mech Ageing Dev 16:97-104. CrossRef Medline

Haverkamp S, Wässle H (2000) Immunocytochemical analysis of the mouse retina. J Comp Neurol 424:1-23. CrossRef Medline

Haverkamp S, Wässle H, Duebel J, Kuner T, Augustine GJ, Feng G, Euler T (2005) The primordial, blue-cone color system of the mouse retina. J Neurosci 25:5438-5445. CrossRef Medline

Helmstaedter M, Briggman KL, Turaga SC, Jain V, Seung HS, Denk W (2013) Connectomic reconstruction of the inner plexiform layer in the mouse retina. Nature 500:168-174. CrossRef Medline

Ichinose T, Lukasiewicz PD (2012) The mode of retinal presynaptic inhibition switches with light intensity. J Neurosci 32:4360-4371. CrossRef Medline

Ichinose T, Shields CR, Lukasiewicz PD (2005) Sodium channels in transient retinal bipolar cells enhance visual responses in ganglion cells. J Neurosci 25:1856-1865. CrossRef Medline

Ikeda H, Wright MJ (1974) Evidence for "sustained" and "transient" neurones in the cat's visual cortex. Vision Res 14:133-136. CrossRef Medline

Jackman SL, Choi SY, Thoreson WB, Rabl K, Bartoletti TM, Kramer RH (2009) Role of the synaptic ribbon in transmitting the cone light response. Nat Neurosci 12:303-310. CrossRef Medline

Koike C, Obara T, Uriu Y, Numata T, Sanuki R, Miyata K, Koyasu T, Ueno S, Funabiki K, Tani A, Ueda H, Kondo M, Mori Y, Tachibana M, Furukawa $\mathrm{T}$ (2010) TRPM1 is a component of the retinal ON bipolar cell transduction channel in the mGluR6 cascade. Proc Natl Acad Sci U S A 107: 332-337. CrossRef Medline

Livingstone MS, Hubel DH (1987) Psychophysical evidence for separate channels for the perception of form, color, movement, and depth. J Neurosci 7:3416-3468. Medline

Livingstone M, Hubel D (1988) Segregation of form, color, movement, and depth: anatomy, physiology, and perception. Science 240:740-749. CrossRef Medline

Ma YP, Cui J, Hu HJ, Pan ZH (2003) Mammalian retinal bipolar cells express inwardly rectifying $\mathrm{K}+$ currents (IKir) with a different distribution than that of Ih. J Neurophysiol 90:3479-3489. CrossRef Medline

MacNeil MA, Heussy JK, Dacheux RF, Raviola E, Masland RH (2004) The population of bipolar cells in the rabbit retina. J Comp Neurol 472:73-86. CrossRef Medline

Masland RH (2001) The fundamental plan of the retina. Nat Neurosci 4:877-886. CrossRef Medline

Molnar A, Werblin F (2007) Inhibitory feedback shapes bipolar cell responses in the rabbit retina. J Neurophysiol 98:3423-3435. CrossRef Medline

Morgans CW, Zhang J, Jeffrey BG, Nelson SM, Burke NS, Duvoisin RM, Brown RL (2009) TRPM1 is required for the depolarizing light response in retinal ON-bipolar cells. Proc Natl Acad Sci U S A 106:19174-19178. CrossRef Medline

Pan ZH (2000) Differential expression of high- and two types of lowvoltage-activated calcium currents in rod and cone bipolar cells of the rat retina. J Neurophysiol 83:513-527. Medline

Pan $\mathrm{ZH}, \mathrm{Hu} \mathrm{HJ}$ (2000) Voltage-dependent $\mathrm{Na}(+)$ currents in mammalian retinal cone bipolar cells. J Neurophysiol 84:2564-2571. Medline

Pan ZH, Hu HJ, Perring P, Andrade R (2001) T-type Ca(2+) channels mediate neurotransmitter release in retinal bipolar cells. Neuron 32:89-98. CrossRef Medline

Pang JJ, Gao F, Wu SM (2004) Light-evoked current responses in rod bipolar cells, cone depolarizing bipolar cells and AII amacrine cells in darkadapted mouse retina. J Physiol 558:897-912. CrossRef Medline

Pang JJ, Gao F, Lem J, Bramblett DE, Paul DL, Wu SM (2010) Direct rod input to cone $\mathrm{BCs}$ and direct cone input to rod $\mathrm{BCs}$ challenge the traditional view of mammalian BC circuitry. Proc Natl Acad Sci U S A 107: 395-400. CrossRef Medline

Pignatelli V, Strettoi E (2004) Bipolar cells of the mouse retina: a gene gun, morphological study. J Comp Neurol 476:254-266. CrossRef Medline

Puthussery T, Venkataramani S, Gayet-Primo J, Smith RG, Taylor WR (2013) $\mathrm{Na}_{\mathrm{V}} 1.1$ channels in axon initial segments of bipolar cells augment input to magnocellular visual pathways in the primate retina. J Neurosci 33:16045-16059. CrossRef Medline

Qian H, Shah MR, Alexander KR, Ripps H (2008) Two distinct processes are evident in rat cone flicker ERG responses at low and high temporal frequencies. Experimental eye research 87:71-75. CrossRef Medline

Saszik S, DeVries SH (2012) A mammalian retinal bipolar cell uses both graded changes in membrane voltage and all-or-nothing $\mathrm{Na}^{+}$spikes to encode light. J Neurosci 32:297-307. CrossRef Medline

Shen Y, Heimel JA, Kamermans M, Peachey NS, Gregg RG, Nawy S (2009) A transient receptor potential-like channel mediates synaptic transmission in rod bipolar cells. J Neurosci 29:6088-6093. CrossRef Medline

Sterling P, Smith RG (2004) Design for a binary synapse. Neuron 41:313315. CrossRef Medline

Sümbül U, Song S, McCulloch K, Becker M, Lin B, Sanes JR, Masland RH, Seung HS (2014) A genetic and computational approach to structurally classify neuronal types. Nat Commun 5:3512. CrossRef Medline

Sun W, Li N, He S (2002a) Large-scale morophological survey of rat retinal ganglion cells. Vis Neurosci 19:483-493. CrossRef Medline

Sun W, Li N, He S (2002b) Large-scale morphological survey of mouse retinal ganglion cells. J Comp Neurol 451:115-126. CrossRef Medline

Völgyi B, Chheda S, Bloomfield SA (2009) Tracer coupling patterns of the ganglion cell subtypes in the mouse retina. J Comp Neurol 512:664-687. CrossRef Medline

Wässle H (2004) Parallel processing in the mammalian retina. Nat Rev Neurosci 5:747-757. CrossRef Medline

Wässle H, Puller C, Müller F, Haverkamp S (2009) Cone contacts, mosaics, and territories of bipolar cells in the mouse retina. J Neurosci 29:106-117. CrossRef Medline

Wu SM (1988) The off-overshoot responses of photoreceptors and horizontal cells in the light-adapted retinas of the tiger salamander. Exp Eye Res 47:261-268. CrossRef Medline

Wu SM, Gao F, Maple BR (2000) Functional architecture of synapses in the inner retina: segregation of visual signals by stratification of bipolar cell axon terminals. J Neurosci 20:4462-4470. Medline

Yonehara K, Farrow K, Ghanem A, Hillier D, Balint K, Teixeira M, Jüttner J, Noda M, Neve RL, Conzelmann KK, Roska B (2013) The first stage of cardinal direction selectivity is localized to the dendrites of retinal ganglion cells. Neuron 79:1078-1085. CrossRef Medline

Zenisek D, Henry D, Studholme K, Yazulla S, Matthews G (2001) Voltagedependent sodium channels are expressed in nonspiking retinal bipolar neurons. J Neurosci 21:4543-4550. Medline

Zhang AJ, Wu SM (2009) Receptive fields of retinal bipolar cells are mediated by heterogeneous synaptic circuitry. J Neurosci 29:789-797. CrossRef Medline 